Journal of Agriculture and Natural Resources (2018) 1(1): 223-230

ISSN: 2661-6270 (Print), ISSN: 2661-6289 (Online)

Research Article

\title{
Effect of heat stress on crossbred dairy cattle in tropical Nepal: Impact on blood parameters
}

\author{
Tulasi Prasad Paudel $*^{1}$, Buddhi Ram Acharya ${ }^{1}$, Dainik Bahadur Karki ${ }^{2}$ and Bhola Shankar \\ Shrestha ${ }^{1}$ \\ ${ }^{1}$ Nepal Agricultural Research Council (NARC), Sinhadarbar Plaza, Kathmandu \\ ${ }^{2}$ Agriculture and Forestry University (AFU), Rampur, Chitwan \\ * Correspondence: harmfree@ gmail.com \\ ORCID: https://orcid.org/0000-0003-0840-9946
}

Received: July 18; Accepted: October 27; Published: December 09.

(C) Copyright: Paudel et al. (2018).

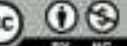

This work is licensed under a Creative Commons Attribution-NonCommercial 4.0 International License.

\begin{abstract}
Chitwan district of Nepal has been known as the dairy kingdom of the country considering its strategic location and potential to easily provision inputs and produce as well as market quality milk across the country. However, the climate especially during summer has been a challenge to farmers that potentially compromise the daily milk yield of cows. Therefore, sixteen crossbred dairy cattle were placed in a RCBD fashion to assess the impacts of cold water bathing in ameliorating effect of heat stress on their performance and body physiology. Routine assessment of the microclimate within the experimental shed and blood parameters was made. The results from the experiment inferred that frequency of bathing (none, once, twice or thrice a day) did not have any significant impact on Haemoglobin, Haematocrit, Sodium, Potassium, Chloride and Bicarbonate levels in the blood plasma(p>0.05). In addition, the animals did not exhibit any signs of physiological distress clinically either. A detailed study scoping temperature humidity index and over a number of other milk and blood parameters are to be tested across a number of other available breeds too in order for the researchers to come to a meaningful strategy to beat the heat stress.
\end{abstract}

Keywords: Heat Stress, Salt balance, Haematology

Correct citation: Paudel, T.P., Acharya, B.R., Karki, D.B., \& Shrestha, B.S. (2018). Effect of heat stress on crossbred dairy cattle in tropical Nepal: Impact on blood parameters. Journal of Agriculture and Natural Resources, 1(1), 223-230. 
Journal of Agriculture and Natural Resources (2018) 1(1): 223-230

ISSN: 2661-6270 (Print), ISSN: 2661-6289 (Online)

\section{INTRODUCTION}

There is general agreement that average temperatures in Nepal increased at an annual rate of $0.06^{\circ} \mathrm{C}$ between 1977 and 2000 , with a $0.04^{\circ} \mathrm{C}$ increases in the terai and $0.08^{\circ} \mathrm{C}$ increases in the Himalayas (Malla, 2009). Warming patterns have been most pronounced at higher altitudes and more so during the winter months as opposed to the terai and monsoon season. Warming has also been greater in the western half of the country than in its eastern counterpart (Chhetri \& Easterling, 2010). The climatic conditions of our country vary from place to place in accordance with the geographical features. In the north, summers are cool and winter are severe, while in the south, summers are very warm and winters are mild. An average temperature drop of $6^{\circ} \mathrm{C}$ occurs for every $1000 \mathrm{~m}$ increase in altitude. In the terai, summer temperatures exceed $37^{\circ} \mathrm{C}$ and higher in some areas, winter temperatures range from $7^{0} \mathrm{C}$ to $23^{\circ} \mathrm{C}$ in terai. The average temperature of Chitwan in summer (May, June and July) has been observed to be maximum $33^{\circ} \mathrm{C}$ and minimum $25.3^{0} \mathrm{C}$ (Anonymous, 2015). Extreme climatic conditions affect the performance of dairy cattle and rather extremities of either hot or cold further exacerbates the condition by affecting the normal physiology of all classes of animals (Paudel \& Perrera, 2009). Hot environments affect the performance of dairy cattle in a variety of different ways. In lactating Holstein cows, for example, the comfortable temperature is within the range $4-24^{\circ} \mathrm{C}$ (Hahn 1981; Roenfeldt, 1998). The effects of heat stress on the cows usually begin to be observed above $24^{\circ} \mathrm{C}$, and markedly observable decline in milk yield start to be visible above $27^{\circ} \mathrm{C}$ (Johnson 1965).In this light, heat stress for dairy cows can be understood to indicate all high temperature related forces that induce adjustments occurring from the sub-cellular to the whole animal level to help the cow cope with physiological dysfunction and to better fit to environment (Yousef, 1985). The endeavour by homeotherms to stabilize body temperature within fairly narrow limits is essential to control biological reactions and physiological processes associated with normal metabolism (Shearer \& Beede, 1990). In order to maintain homeothermy, an animal must be within thermal equilibrium which is further affected by factors like radiation, air temperature, air movement and humidity.

A study was, therefore, carried out in one of the tropical climatic set-up of Nepal, to assess the impact of summer heat on body physiology especially reflected by blood parameters and evaluate bathing as a rehabilitation strategy to overcome such stressful condition.

\section{MATERIALS AND METHODS}

\section{The study area and period}

The study was carried out at during the summer months of 2015 (May-July) at experimental station of National Cattle Research Program (NCRP) in Rampur, Chitwan $\left(27^{\circ} 39^{\prime} \mathrm{N}\right.$ and $\left.84^{\circ} 21^{\prime} \mathrm{E}\right), 10 \mathrm{~km}$ west of district headquarter, Bharatpur. Climatically, Chitwan harbours the tropical climate and yet is one of the most important dairy pockets of Nepal, largely due to the high demand of fluid milk, easy availability of feeds, straw, veterinary services favouring commercialization of dairy farming. 
Journal of Agriculture and Natural Resources (2018) 1(1): 223-230

ISSN: 2661-6270 (Print), ISSN: 2661-6289 (Online)

\section{Sample size, design and treatment groups}

All together sixteen lactating cattle were used for the study and fit into completely randomized block design (RCBD). Blocking was done on the basis of the parity of the animals selected for the study. The following list explains the treatment arrangement of the experiment.

\section{Treatment group}

$\mathrm{T}_{1}$ : Bathing once in a day (12:00 hours)

$\mathrm{T}_{2}$ : Bathing twice (12:00 and 15:00 hours)

$\mathrm{T}_{3}$ : Bathing thrice (9:00, 12:00 and15 hours)

$\mathrm{T}_{4}$ : Control (no bathing)

\section{Data collection and analysis}

Meteorological data (maximum, minimum, dry bulb and wet bulb temperature in centigrade) were collected from inside the shed every morning at 9:00 hours. Likewise, vital signs were collected three times daily (at 9:00, 12:00 and 15 hours) every fortnight during the trial period. Any aberrations to the vital signs and animal behaving other than their normal behavior were closely monitored. Provisions were made in a way that any animal distressed due to the experiment will be treated and taken out of the experiment considering the study's alignment with the standard animal ethics protocol.

The blood samples were collected in vacutainer tube at morning time. Blood parameters sodium $(\mathrm{Na})$, potassium $(\mathrm{K})$, chloride $(\mathrm{Cl})$, bicarbonate, Hemoglobin and Hematocrit were analyzed three times ( 0,45 and 90 days) during the experiment at the laboratory in Bharatpur, Chitwan following the method described by Obitsu et al. (2011). The blood samples were collected in vacutainer tubes in mornings.

Collected data were assembled and processed and cleaned with the use of MS Excel (version 16.16.4) and differences among the means using different models has been carried out using SPSS ${ }^{\text {TM }}$ Statistical Software (version 23). All the recorded data were subjected to analysis of variance and Duncan's multiple range test (DMRT) for mean separation. The significance differences among the means were tested using least significance difference (LSD) at 5\% level of significance (Gomez and Gomez, 1984).

\section{RESULTS AND DISCUSSION}

\section{Microclimatic condition inside the cattle shed}

The climatic conditions of inside the shed were presented in table 1. In which the average of maximum, minimum, dry bulb and wet bulb temperature were found $35.36 \pm 0.25,27.39 \pm 0.18$, $30.69 \pm 0.16$ and $26.07 \pm 0.15^{\circ} \mathrm{C}$ respectively. These types of climatic condition are not suitable for the jersey cattle. 
Journal of Agriculture and Natural Resources (2018) 1(1): 223-230

ISSN: 2661-6270 (Print), ISSN: 2661-6289 (Online)

Hagiwara et al. (2002) reported that the environmental temperature at which the respiration rate started to increase was lower $\left(17^{\circ} \mathrm{C}\right)$ for high-producing cows $\left(>35 \mathrm{~kg}\right.$ milk/day) than that $\left(22^{\circ} \mathrm{C}\right)$ of low producing cows. The research studied that lactating dairy cows from European breeds, the thermos-neutral zone ranges between -5 and $25^{\circ} \mathrm{C}$, and are called lower critical temperature (LCT) and upper critical temperature (UCT) respectively meaning animals require no additional energy above maintenance to cool or heat their body (Johnson, 1987).

Table1. Meteorological data of inside the cattle shed during the experimental period

\begin{tabular}{lcccc}
\hline Variable & $\begin{array}{c}\text { No. of } \\
\text { observation }\end{array}$ & \multicolumn{3}{c}{ Temperatures $\left.{ }^{\mathbf{0}} \mathbf{C}\right)$} \\
\cline { 3 - 5 } & 90 & $35.36 \pm 0.25$ & 30.00 & Mean \\
\hline Maximum temperature & 90 & $27.39 \pm 0.18$ & 23.00 & 33.00 \\
Minimum temperature & 90 & $30.69 \pm 0.16$ & 27.00 & 35.00 \\
Dry bulb temperature & 90 & $26.07 \pm 0.15$ & 22.00 & 28.50 \\
Wet bulb temperature & & & \\
\hline
\end{tabular}

\section{Blood parameter of cross bred cattle}

\section{Sodium (Na) and Potassium (K) in cattle blood}

The sodium and potassium in blood were analyzed of the experimental animal of different treatment groups in three times $(0,45$ and 90 days) during the research period which are presented in table 2. The results of sodium in cattle blood during the summer condition of different treatment group were found statistically non-significant. The result of next important blood parameter potassium was found mid time (40 days) statistically significant and other initial and final days result were found non-significant.

Table2. Effect of cold water bathing on blood Sodium and potassium values during summer

\begin{tabular}{lcccccc}
\hline Treatment & \multicolumn{3}{c}{ Na $(\mathbf{m m o l} / \mathbf{l})$ in days } & \multicolumn{3}{c}{ K (mmol/l) in days } \\
\cline { 2 - 7 } & $\mathbf{0}$ & $\mathbf{4 5}$ & $\mathbf{9 0}$ & $\mathbf{0}$ & $\mathbf{4 5}$ & $\mathbf{9 0}$ \\
\hline $\mathrm{T}_{1}$ & $144.25 \pm 1.03$ & $145.88 \pm 0.95$ & $145.70 \pm 2.72$ & $4.20 \pm 0.15$ & $4.60 \pm 0.04$ & $4.48 \pm 0.05$ \\
$\mathrm{~T}_{2}$ & $143.40 \pm 1.64$ & $143.23 \pm 2.00$ & $145.50 \pm 1.47$ & $4.30 \pm 0.11$ & $4.65 \pm 0.01$ & $4.65 \pm 0.06$ \\
$\mathrm{~T}_{3}$ & $144.00 \pm 1.06$ & $144.75 \pm 1.30$ & $143.65 \pm 0.97$ & $4.18 \pm 0.11$ & $4.40 \pm 0.04$ & $4.40 \pm 0.15$ \\
$\mathrm{~T}_{4}$ & $144.05 \pm 0.61$ & $148.90 \pm 2.60$ & $144.90 \pm 1.56$ & $4.13 \pm 0.13$ & $4.55 \pm 0.05$ & $4.28 \pm 0.09$ \\
\hline $\mathrm{F}$ value & 0.10 & 1.60 & 0.21 & 0.42 & 4.67 & 3.55 \\
\hline
\end{tabular}

Note: T1: Bathing once in a day (12 noon), T2: Bathing twice (12 noon and 3 pm), T3: Bathing thrice (9 am, 12 noon and $3 \mathrm{pm}$ ) and T4: Control (no bathing)

\section{Chloride and Bicarbonate in cattle blood}

The Chloride and Bicarbonate were analyzed in three times (on 0, 45 and 90 days) during the experiment. Results are presented in table 3 and both chloride and bicarbonate values across treatment did not show significant differences. 
Journal of Agriculture and Natural Resources (2018) 1(1): 223-230

ISSN: 2661-6270 (Print), ISSN: 2661-6289 (Online)

Table3.Effect of cold water bathing on blood Chloride and bicarbonate levels during summer

\begin{tabular}{lcccccc}
\hline Treatment & \multicolumn{3}{c}{ Chloride $(\mathbf{m m o l} / \mathbf{l})$ in days } & \multicolumn{3}{c}{ Bicarbonate (mmol/l) in days } \\
\cline { 2 - 7 } & $\mathbf{0}$ & $\mathbf{4 5}$ & $\mathbf{9 0}$ & $\mathbf{0}$ & $\mathbf{4 5}$ & $\mathbf{9 0}$ \\
\hline $\mathrm{T}_{1}$ & $107.70 \pm 1.08$ & $103.95 \pm 0.79$ & $108.28 \pm 3.13$ & $22.25 \pm 1.55$ & $21.50 \pm 1.66$ & $19.50 \pm 1.32$ \\
$\mathrm{~T}_{2}$ & $106.00 \pm 2.04$ & $102.33 \pm 0.48$ & $107.15 \pm 1.18$ & $22.25 \pm 1.79$ & $20.75 \pm 1.03$ & $18.75 \pm 1.03$ \\
$\mathrm{~T}_{3}$ & $104.98 \pm 1.99$ & $106.80 \pm 1.64$ & $108.98 \pm 0.84$ & $21.75 \pm 1.93$ & $21.50 \pm 1.26$ & $18.00 \pm 1.35$ \\
$\mathrm{~T}_{4}$ & $104.26 \pm 0.83$ & $105.66 \pm 1.47$ & $109.15 \pm 2.08$ & $24.00 \pm 1.78$ & $17.75 \pm 0.75$ & $19.25 \pm 0.63$ \\
\hline $\mathrm{F}$ value & 0.85 & 2.98 & 0.15 & 0.27 & 1.94 & 0.37 \\
\hline
\end{tabular}

Note: T1: Bathing once in a day (12 noon), T2: Bathing twice (12 noon and $3 \mathrm{pm})$, T3: Bathing thrice (9 am, 12 noon and $3 \mathrm{pm}$ ) and T4: Control (no bathing)

Coppock et al. (1982) was perhaps the first to report the effects of heat stress on electrolyte balance of dairy cows ultimately affecting the buffering capacity of the body and thereby the entire body physiology. However, as reported, the current study did not show any decline in the electrolyte levels both in terms of Chloride and Bicarbonate across all sampling days. Likewise, the excess drain of these salt has not been clinically evidenced during the experiment since excess draining are often associated with conditions like alkanosis or acidotic conditions (Afzaal et al., 2004). The other associated risks of kidneys reabsorbing or liberating the ions under excessive flushing of these electrolytes were not assessed (Gaynor et al., 1989).

\section{Haemoglobin (Hb) and Haematocrit(Ht)in cattle blood}

The blood haemoglobin and haematocrit of the experimental animals with the interval of 45 days during the research period of the different treatment groups of normal water bathing in summer condition are presented in table 4 . The results of $\mathrm{Hb}$ and $\mathrm{Ht}$ analysis also statistically were found non-significant.

Table4. Effect of cold water bathing on Haemoglobin $(\mathrm{Hb})$ and Haematocrit(Ht) values in blood of cattle during summer

\begin{tabular}{lcccccc}
\hline Treatments & \multicolumn{3}{c}{ Hb\% in days } & \multicolumn{3}{c}{ Ht \% in days } \\
\cline { 2 - 7 } & $\mathbf{0}$ & $\mathbf{4 5}$ & $\mathbf{9 0}$ & $\mathbf{0}$ & $\mathbf{4 5}$ & $\mathbf{9 0}$ \\
\hline $\mathrm{T}_{1}$ & $10.53 \pm 1.31$ & $8.28 \pm 0.33$ & $8.05 \pm 0.38$ & $32.00 \pm 3.54$ & $22.66 \pm 1.43$ & $24.50 \pm 0.96$ \\
$\mathrm{~T}_{2}$ & $9.53 \pm 0.50$ & $7.66 \pm 0.25$ & $7.70 \pm 0.30$ & $29.25 \pm 1.49$ & $22.50 \pm 0.96$ & $24.00 \pm 1.58$ \\
$\mathrm{~T}_{3}$ & $10.28 \pm 0.05$ & $8.58 \pm 0.40$ & $7.05 \pm 0.67$ & $32.25 \pm 1.25$ & $24.80 \pm 1.58$ & $21.75 \pm 2.14$ \\
$\mathrm{~T}_{4}$ & $10.08 \pm 0.46$ & $7.85 \pm 0.75$ & $8.10 \pm 0.62$ & $31.50 \pm 0.87$ & $22.00 \pm 1.15$ & $24.00 \pm 1.41$ \\
\hline $\mathrm{F}$ value & 0.47 & 0.68 & 0.82 & 0.49 & 0.82 & 0.59 \\
\hline
\end{tabular}

Note: T1: Bathing once in a day (12 noon), T2: Bathing twice (12 noon and 3 pm), T3: Bathing thrice (9 am, 12 noon and $3 \mathrm{pm}$ ) and T4: Control (no bathing)

Ali-Gholi et al. (2007) described that $\mathrm{Ht}$ value, Hb concentration and erythrocyte number rise, especially at the beginning of hot period, evidenced a rise of blood concentration. This hemoconcentration was initially induced by an increase in erythrocyte number, later by plasma dehydration (Obitsu et al., 2011; Lamp et al., 2015). Toharmat and Kume (1997) did not find any significant difference between $\mathrm{Ht}$ value and $\mathrm{Hb}$ concentration in hot and cool weather. In further work, however, Toharmat et al. (1998) described an increase in hematocrit values and hemoglobin concentration in summer. They also described a significant decrease in Ht value in 
dairy cows exposed to high temperatures. Ht and red blood cells decrease were perhaps caused by a rise in erythrocyte destruction, hemodilution effect could also participate here, because more water was transported in circulatory system for evaporative cooling. Another similar result was found that, cooling by sprinkling prevented marked changes in red blood picture, only nonsignificant increase in Ht value and erythrocyte number occurred at the beginning. However, it is also reported that cooling of heat stressed dairy cows increased blood hemoglobin concentration (Aboulnaga et al., 1989).

\section{CONCLUSION}

This study assessed the clinical and sub-clinical impacts of heat stress, among others, on the animal performances especially in terms of blood parameters. The results obtained from the study did not, however, confer to the recommendation and hypothesis that extremities of climate are expressed in terms of body physiology and can be measured through electrolyte balance in the blood. This could perhaps be due to the reason that either the animals have already been more or less suited to local harshness of summer or the temperature humidity index could perhaps be the right parameter to get more impressive results as part of the study (Ganter et al., 2011). On the other hand, the thermoneutral zone of different breeds vary and a more detailed study scoping the breed effect is also deemed essential.

\section{ACKNOWLEDGEMENTS}

The authors would like to express their gratitude to Dr. Madhav P Acharya and the entire NCRP team in facilitating the team in carrying out the experiment and NARC for the funding support.

\section{Author Contributions}

T.P.P. designed and performed experiments, analyzed data and wrote the paper; B.R.A. helped during conducting the experiments and recording observations. D.B.K. and B.S.S. helped to revise the manuscript.

\section{Conflicts of Interest}

The authors declare that there is no conflict of interest regarding the publication of this paper.

\section{REFERENCES}

Aboulnaga, A. I., Kamal, T. H., El-Masry, K. A., \& Marai, I. F. (1989). Short-term response of spray cooling and drinking cold water for improving milk production of heat stressed Friesian cows. In Proceedings of the 3rd Egyptian British Conference on animals, fish and poultry production, Alexandria, Egypt.

Afzaal, D., Nisa, M., Khan, M. A., \& Sarwar, M. (2004). A Review on Acid Base Status in Dairy Cows: Implications of Dietary Cation-Anion Balance. Pakistan Veterinary Science Journal, 24(4), 199-202. 
Journal of Agriculture and Natural Resources (2018) 1(1): 223-230

ISSN: 2661-6270 (Print), ISSN: 2661-6289 (Online)

Ali-Gholi, R., Asri-Rezaie, S., \& Daryoush, M. (2007).Influence of the short-term road transport stress on blood parameters in cows. Medycyna Wet, 63(11), 1311-1315

Anonymous, (2015). http://welcomenepal.com/promotional/know-nepal/climate/2015/2/22

Chhetri, N. B., \& Easterling, W. E. (2010). Adapting to climate change: retrospective analysis of climate technology interaction in the rice-based farming system of Nepal. Annals of the Association of American Geographers, 100(5), 1156-1176.

Coppock, C. E., Grant, P. A., Portzer, S. J., Charles, D. A., \& Escobosa, A. (1982). Lactating dairy cow responses to dietary sodium, chloride, and bicarbonate during hot weather. Journal of Dairy Science, 65(4), 566-576.

Gantner, V., Mijić, P., Kuterovac, K., Solić, D. \& Gantner, R. (2011). Temperature-humidity index values and their significance on the daily production of dairy cattle. Mljekarstvo, 61(1), 56-63.

Gaynor, P. J., Mueller, F. J., Miller, J. K., Ramsey, N., Goff, J.P., \& Host, R. L. (1989. Parturient hypocalcemia in Jersey cows fed alfalfa haylage based diets with different cation to anion ratios. Journal of Dairy Science, 72, 2525-2532.

Gomez, K. A., \& Gomez, A. A. (1984). Statistical Procedures for Agricultural Research (second edition).New York: John Willey and Sons.

Hagiwara, K., Hiura, C., \& Koutomi, S. (2002). Development of practical method in the early stage discovery of the heat stressed dairy cows and proof of its effective countermeasures. Bulletin of the Kochi Prefectural Livestock Experiment Station (Japan).

Hahn, G. L. (1981). Housing and management to reduce climatic impacts on livestock. Journal of Animal Science, 52(1), 175-186.

Johnson, H. D. (1965). Environmental temperature and lactation (with special reference to cattle). International Journal of Biometeorology, 9(2), 103-116.

Johnson, H.D. (1987). Bioclimates and Livestock, In: World Animal Science B5 Bioclimatology and the Adaptation of Livestock, H.D. Johnson, (Ed.), 3-16, Elsevier Science, ISBN 978044- 4426-90-1, Amsterdam, The Netherlands

Lamp, O., Derno, M., Otten, W., Mielenz, M., Nürnberg, G., \& Kuhla, B. (2015). Metabolic heat stress adaption in transition cows: Differences in macronutrient oxidation between Lategestating and early-lactating German holstein dairy cows. PLoS ONE 10(5): e0125264. doi:10.1371/journal. pone.0125264

Malla, G. (2009). Climate change and its impact on Nepalese Agriculture. Journal of Agriculture and Environment, 9, 62-71.

Obitsu, T., Kamiya, M., Kamiya, Y., Tanaka, M., Sugino, T., \& Taniguchi, K. (2011). Effects of high ambient temperature on urea-nitrogen recycling in lactating dairy cows. Animal Science Journal 82(4), 531-6. doi: 10.1111/j.1740-0929.2011.00880.x

Paudel, T. P., \& Perrera, K. (2009). Managing Adverse Climatic Conditions. Dairy Nutrition Handbook of Nepal. (PH Robinson and U Krishnamoorthy eds.) American Soybean Association

Roenfeldt, S. (1998). You can't afford to ignore heat stress. Dairy manage,35(5), 6-12.

Shearer, J. K., \& Beede, D. K. (1990). Thermoregulation and physiological responses of dairy cattle in hot weather. Agri-practice, 11(4). 
Journal of Agriculture and Natural Resources (2018) 1(1): 223-230

ISSN: 2661-6270 (Print), ISSN: 2661-6289 (Online)

Toharmat, T., \& Kume, S. (1997). Effect of heat stress on minerals concentration in blood and colostrum of heifers around parturition. Asian Australasian Journal of Animal Sciences, 10, 298-303.

Toharmat, T., Nonaka, I., Shimizu, M., Batajoo, K. K., \& Kume, S. (1998). Effects of preparlum energy intake and calving season on blood composition of periparturient cows. Asian Australasian Journal of Animal Sciences, 11, 739-745.

Yousef, M. K. (1985). Stress physiology in livestock. Volume III. Poultry. CRC Press Inc. 